\title{
Modeling the Impact of Girl Child Empowerment amid Boy Child Neglect on Singlehood in Kakamega County
}

\author{
Odero Everlyne Akoth \\ Department of Mathematics, Masinde Muliro University of Science and Technology, Kakamega, Kenya \\ Email: eodero@mmust.ac.ke
}

How to cite this paper: Akoth, O.E. (2022) Modeling the Impact of Girl Child Empowerment amid Boy Child Neglect on Singlehood in Kakamega County. Open Journal of Statistics, 12, 109-117.

https://doi.org/10.4236/ojs.2022.121008

Received: January 18, 2022

Accepted: February 21, 2022

Published: February 24, 2022

Copyright $\odot 2022$ by author(s) and Scientific Research Publishing Inc. This work is licensed under the Creative Commons Attribution International License (CC BY 4.0).

http://creativecommons.org/licenses/by/4.0/

\begin{abstract}
In Kenya today, we are experiencing an increase in the number of boy child dropping out of school thus making the female figure to be ahead as far as development agenda is concerned. There is increase in singlehood due to one's own choice, separation and divorce because boy child does not feel empowered to take up their roles as heads of families later in life. A lot is documented about single hood but information about impact of girl child empowerment amid boy child neglect on singlehood is minimally captured in literature. This study empirically modeled the impact of girl child empowerment amid boy child neglect on single hood in Kakamega County. The study employed sample survey method of data collection. Single hoods of age 30 years and above formed the study population. The data was collected using questionnaires and analyzed by use of Chi-Squares to test the degree of relationship between the variables of study and singlehood. Linear regression analysis was also used to come up with a model of how the variables of study influenced singlehood in the county. The study revealed negative correlation between girl child empowerment and singlehood and a positive correlation between boy child neglect and singlehood. The findings are expected to be useful to stakeholders in Kakamega County when designing appropriate plan of action to empower both boy child and girl child alike.
\end{abstract}

\section{Keywords}

Singlehood, Girl Child Empowerment, Boy Child Neglect

\section{Introduction}

Singlehood in this context refers to a state of being thirty-five years and above and unmarried due to either; own choice, separation or divorce. This group of individuals is on the increase in Kenya and elsewhere in Africa today [1]. In the 
year 2000, the National Council of Churches of Kenya (NCCK), in their research observed that, in the past, most African societies had norms that were strictly observed, and as a result, safeguarded against single-hood. To date, the family has undergone many changes. Besides the nuclear and extended family types, singlehood situations have come into existence and are on the rise due to various factors such as the current socio-economic realities among others [2].

Darlock in 2013 observed an explosion of singlehood in Kenya as many well educated and financially independent women were opting for parenthood without marriage [3] [4]. This trend apparently streams from the changes brought about by modernity, formal education and financial empowerment among women while neglecting to empower the boy child, the one whom society looks unto to take the role of a bread winner in the house. Usually, the boy child is left unempowered as he grows up while all attention is given to the girl child. The society therefore misses out on preparing future husbands, heads of houses and hence fathers.

A lot is documented about socio-economic factors as impacts that lead to singlehood [5] [6]. However, not much is captured about girl child empowerment amid boy child neglect as a factor that fuels singlehood in our societies. That is what formed the basis for this study.

\subsection{Objective of Study}

The main objective of this study was to empirically investigate how girl child empowerment amid boy child neglect has impacted on singlehood in Kakamega County.

\subsection{Significance of Study}

The results of this study inform the stakeholders that neglecting the boy child while only empowering the girl child is a fuel towards the rise of numbers of singlehoods. Therefore, the findings from this study will assist stake holders, policy makers and church leaders to incorporate ways of equal empowerment to both boys and girls.

\subsection{Conceptual Framework}

\section{Independent Variables}

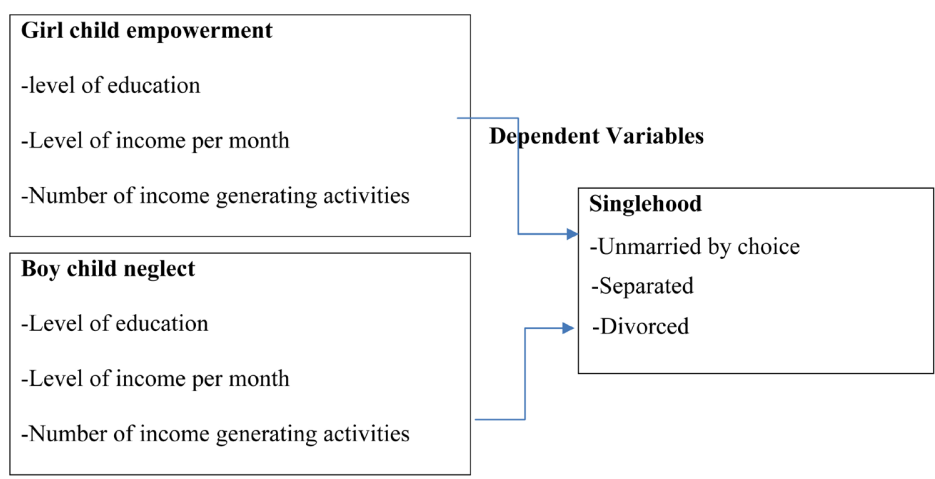




\section{Literature Review}

There are numerous initiatives worldwide seeking to empower the girl child and women as a whole. Some of these initiatives in Kenya include; Girl Child Education Support Initiative, Girl's, and Women's Education Initiative, Girl Child Art Foundation Campus Initiative, Samburu Girls Foundation and many more. Most of them seek to support orphaned girl child. More opportunities are prioritized to women even in circumstances where both sexes are vulnerable regardless of gender. This is even displayed in the Kenyan constitution of 2010 on representation especially in the senate for the position of Women Representative whereas there is no man representative position [7]. Similar organizations are missing for the boy child.

On 10th of December, 1948 the General Assembly of the United Nations adopted and proclaimed the Universal Declaration of the Human Rights which described all human beings as equal and deserves equal opportunities, respect and recognition of their rights disregard of sex, age, race, language, color, national or social origin, property, birth or other status [8]. This was later on seen to be contradicted by the Fourth World Conference on Women dubbed the Beijing Declaration and Platform for Action held on 15th of September 1995 in Beijing China; which had emphasis on privileges towards girl child and women development [9].

Many organizations go by the adage that girls are more vulnerable than boys, hence, they empower girls more [10]. As a result, Women are a more empowered lot [11]. The empowering of women has led to men being left feeling ignored since they were viewed as less vulnerable compared to the girls [12]-[17]. This neglect is noticed in his bid to find his bearing, the boy child has now turned to vices such as drugs and substance abuse, sexual abuse and dropping out of school [18].

Due to neglect of the boy child, many marriages do not last, leading to a lot of separations and divorce. Some men also decide just to remain unmarried due to lack of empowerment [19] [20] [21] [22].

Studies centering on the impact of girl child empowerment amid boy child neglect is minimal in literature hence a knowledge gap that this study filled.

\section{Results}

\subsection{Impact of Girl Child Empowerment on Singlehood in Kakamega County}

Results of Table 1 indicate that 22 out of 31 women who were separated had their level of income between Ksh 10,000 - Ksh 50,000. It is also evident in the table that none of the women who were divorced or separated, had zero level of income per month. The results also showed that as the level of income increases, singlehood also increases. There is thus a positive relationship between the level of income of women and their marital status. 
Table 1. Level of income of females versus marital status for females.

\begin{tabular}{|c|c|c|c|c|c|}
\hline & \multicolumn{3}{|c|}{ Marital status for females } & \multirow{2}{*}{ Total } \\
\hline & & Single by choice & Divorced & Separated & \\
\hline \multirow{4}{*}{$\begin{array}{c}\text { Income per } \\
\text { month for } \\
\text { females }\end{array}$} & below 1000 & 2 & 0 & 0 & 2 \\
\hline & $1000-10,000$ & 2 & 12 & 0 & 14 \\
\hline & $10,000-50,000$ & 0 & 3 & 22 & 25 \\
\hline & above 50,000 & 0 & 0 & 9 & 9 \\
\hline \multicolumn{2}{|c|}{ Total } & 4 & 15 & 31 & 50 \\
\hline
\end{tabular}

The results of Table 2 indicate that there is a significant relationship between the level of income of females and their marital status. $\mathrm{P}<0.05(\mathrm{df}=6, \mathrm{P}=$ $0.0001)$.

Results of Table 3 showed that majority of the women who were separated (18 out of 31) had their level of education being mid-level college and above. Also, none of the single women had primary level of education.

Table 4 results indicated that there was a significant relationship between the level of education for women and marital status. $\mathrm{P}<0.05(\mathrm{df}=6, \mathrm{P}=0.0001)$.

Results of Table 5 showed that all the women who were separated (31 out of 31) had two or more income generating activities.

Table 6 indicated that there was a significant relationship between number of income generating activities of women and marital status. $\mathrm{P}<0.05(\mathrm{df}=6, \mathrm{P}=$ $0.0001)$.

\subsection{Impact of Boy Child Neglect on Singlehood in Kakamega County}

Results from Table 7 presented count of singlehood males with different levels of income per month. The table showed that majority of the men who were separated (10 out of 16) had their level of income below Ksh 1000. It's also worth noting from the table that none of the men who were divorced or separated had above Ksh 50,000 and above level of income per month.

The results of Table 8 indicate that there is a significant relationship between the level of income of males and their marital status. $\mathrm{P}<0.05(\mathrm{df}=6, \mathrm{P}=0.049)$.

Results of Table 9 showed that only one man out of 30 men was single by choice. Majority of the men who were separated (9 out of 16) had their level of education being secondary.

The results of Table 10 indicate that there is a significant relationship between the level of education of men and their marital status. $\mathrm{P}<0.05$ ( $\mathrm{df}=6, \mathrm{P}=$ $0.0001)$.

Results of Table 11 showed that majority of the men who were separated (12 out of 16) had only one income generating activities. Also, no single man had 2 or more income generating activities. Hence, the lower the income generating activities the higher a man was prone to singlehood. 
Table 2. Relationship between level of income of females and their marital status.

\begin{tabular}{cccc}
\hline \multicolumn{4}{c}{ Chi-Square Tests } \\
\hline & Value & df & Asymptotic Significance (2-sided) \\
\hline Pearson Chi-Square & 59.799 & 6 & 0.0001 \\
N of Valid Cases & 50 & & \\
\hline
\end{tabular}

Table 3. Highest level of education for females versus marital status for females.

\begin{tabular}{cccccc}
\hline & & \multicolumn{3}{c}{ marital status for females } & \multirow{2}{*}{ Total } \\
\cline { 3 - 5 } & primary & 0 & 0 & 0 & 0 \\
\hline \multirow{2}{*}{$\begin{array}{c}\text { single by choice } \\
\text { of education } \\
\text { for females }\end{array}$} & secondary & 0 & 3 & 13 & 16 \\
& mid level college & 4 & 8 & 13 & 25 \\
& university & 0 & 4 & 5 & 9 \\
& Total & 4 & 15 & 31 & 50 \\
\hline
\end{tabular}

Table 4. Relationship between level of education for females and marital status for females.

\begin{tabular}{cccc}
\hline \multicolumn{4}{c}{ Chi-Square Tests } \\
\hline & Value & df & Asymptotic Significance (2-sided) \\
\hline $\begin{array}{r}\text { Pearson Chi-Square } \\
\text { N of Valid Cases }\end{array}$ & 38.862 & 6 & 0.0001 \\
\hline
\end{tabular}

Table 5. Number of income generating activities for females versus marital status.

\begin{tabular}{|c|c|c|c|c|c|}
\hline & & \multicolumn{3}{|c|}{ marital status for females } & \multirow{2}{*}{ Total } \\
\hline & & single by choice & divorced & separated & \\
\hline \multirow{4}{*}{$\begin{array}{l}\text { number of } \\
\text { income } \\
\text { generating } \\
\text { activities for } \\
\text { females }\end{array}$} & 0 & 1 & 0 & 0 & 1 \\
\hline & 1 & 3 & 5 & 0 & 8 \\
\hline & 2 & 0 & 10 & 11 & 21 \\
\hline & more than 2 & 0 & 0 & 20 & 20 \\
\hline \multicolumn{2}{|c|}{ Total } & 4 & 15 & 31 & 50 \\
\hline
\end{tabular}

Table 6. Relationship between Number of income generating activities for females and marital status for females.

\begin{tabular}{cccc}
\hline \multicolumn{4}{c}{ Chi-Square Tests } \\
\hline & Value & df & Asymptotic Significance (2-sided) \\
\hline Pearson Chi-Square & 44.404 & 6 & 0.0001 \\
N of Valid Cases & 50 & & \\
\hline
\end{tabular}


Table 7. Level of income of males versus marital status for males.

\begin{tabular}{cccccc}
\hline & & \multicolumn{3}{c}{ marital status for males } & \multirow{2}{*}{ Total } \\
\cline { 3 - 5 } & below 1000 & 1 & 4 & 10 & 15 \\
\hline \multirow{2}{*}{$\begin{array}{c}\text { single by choice } \\
\text { month for }\end{array}$} & $1000-10,000$ & 0 & 9 & 2 & 11 \\
males & $10,000-50,000$ & 0 & 2 & 2 & 4 \\
& above 50,000 & 0 & 0 & 0 & 0 \\
& Total & 1 & 15 & 14 & 30 \\
\hline
\end{tabular}

Table 8. Relationship between level of income of males and marital status for males.

\begin{tabular}{cccc}
\hline \multicolumn{4}{c}{ Chi-Square Tests } \\
\hline & Value & df & Asymptotic Significance (2-sided) \\
\hline Pearson Chi-Square & 12.643 & 6 & 0.049 \\
N of Valid Cases & 30 & & \\
\hline
\end{tabular}

Table 9. Highest level of education for males versus marital status for males.

\begin{tabular}{cccccc}
\hline & & \multicolumn{3}{c}{ marital status for males } & \multirow{2}{*}{ Total } \\
\cline { 3 - 5 } & & single by choice & divorced & separated \\
\hline \multirow{3}{*}{$\begin{array}{c}\text { highest level } \\
\text { of education } \\
\text { for males }\end{array}$} & secondary & 1 & 0 & 0 & 1 \\
& midlevel college & 0 & 8 & 9 & 17 \\
& university & 0 & 5 & 4 & 9 \\
& Total & 1 & 0 & 3 & 3 \\
\hline
\end{tabular}

Table 10. Relationship between level of education for males and marital status for males.

\begin{tabular}{cccc}
\hline \multicolumn{4}{c}{ Chi-Square Tests } \\
\hline & Value & $\mathrm{df}$ & Asymptotic Significance (2-sided) \\
\hline Pearson Chi-Square & 47.206 & 6 & 0.0001 \\
N of Valid Cases & 30 & & \\
\hline
\end{tabular}

Table 11. Number of income generating activities for males versus marital status for males.

\begin{tabular}{cccccc}
\hline & & \multicolumn{3}{c}{ marital status for males } & \multirow{2}{*}{ Total } \\
\cline { 2 - 5 } & & single by choice & divorced & separated & \\
\hline number of income & 0 & 1 & 7 & 4 & 12 \\
generating activities & 1 & 0 & 6 & 12 & 18 \\
for males & 2 & 0 & 0 & 0 & 0 \\
Total & & 1 & 13 & 16 & 30 \\
\hline
\end{tabular}

The results of Table 12 indicated that there is a significant relationship between the level of males income generating activities and their marital status. $\mathrm{P}<$ $0.05(\mathrm{df}=4, \mathrm{P}=0.008)$. 


\subsection{Multiple Linear Regression Modeling of Impact of Girl Child Empowerment amid Boy Child Neglect on Singlehood in Kakamega County}

In this case, we let

$$
Y=B_{0}+B_{1} X_{1}+B_{2} X_{2}
$$

where,

$Y$, represent singlehood, $X_{1}$ represent girl child empowerment, $X_{2}$ represent boy child neglect,

$B_{0}$ and $B_{1}$ represent regression parameters.

Table 13 give us the model parameters (regression coefficients) hence, we extract the model as follows;

$$
Y=1.710 B_{0}-0.252 X_{1}+0.454 X_{2}
$$

where

\section{Interpretation;}

As girl child empowerment increases, singlehood decreases by 0.252 .

As boy neglect increases singlehood increases by 0.454 .

Results of Table 13 showed that as girl child empowerment increases, singlehood decreases by 0.252 while as boy neglect increases singlehood increases by 0.454 .

Results of Table 14 are of Coefficient of Determination (R-square). Coefficient of Determination measures the explanatory power of the independent variables. In Table 14, R-Square is 0.684 hence the model is about $68.4 \%$ explained by the independent variables.

Results of Table 15 tested the adequacy of the model. According to Table 15, $\mathrm{P}$-value $(0.006)<0.05$ hence the model is adequate and significant.

Table 12. Relationship between Number of income generating activities for males and marital status for males.

\begin{tabular}{cccc}
\hline \multicolumn{4}{c}{ Chi-Square Tests } \\
\hline Value & df & Asymptotic Significance (2-sided) \\
\hline Pearson Chi-Square & 13.816 & 4 & 0.008 \\
N of Valid Cases & 30 & & \\
\hline
\end{tabular}

\begin{tabular}{|c|c|c|c|c|c|}
\hline & \multirow{2}{*}{ Model } & \multicolumn{2}{|c|}{ Standardized Coefficients } & \multirow{2}{*}{$\mathrm{t}$} & \multirow{2}{*}{ Sig. } \\
\hline & & B & Std. Error & & \\
\hline \multirow{3}{*}{1} & (Constant) & 1.710 & 0.274 & 6.249 & 0.0001 \\
\hline & $\begin{array}{l}\text { number of income generating } \\
\text { activities for females }\end{array}$ & -0.252 & 0.216 & -1.165 & 0.254 \\
\hline & $\begin{array}{l}\text { number of income generating } \\
\text { activities for males }\end{array}$ & 0.454 & 0.194 & 2.338 & 0.027 \\
\hline
\end{tabular}

Table 13. Regression coefficients for the multiple linear regression model. 
Table 14. Coefficient of determination for the multiple linear regression model.

\begin{tabular}{ccccccc}
\hline \multirow{2}{*}{ Model } & \multirow{2}{*}{$\begin{array}{c}\mathrm{R} \\
\text { Square }\end{array}$} & Adjusted & Std. Error & \multicolumn{3}{c}{ Change Statistics } \\
\cline { 5 - 7 } & R Square & of the Estimate & F Change & df & Sig. F Change \\
\hline 1 & 0.684 & 0.123 & 0.436 & 3.036 & 2 & 0.048 \\
\hline
\end{tabular}

Table 15. Testing adequacy for the multiple linear regression model.

\begin{tabular}{ccccccc}
\hline & Model & Sum of Squares & df & Mean Square & F & Sig. \\
\hline & Regression & 1.157 & 2 & 0.578 & 3.036 & 0.006 \\
1 & Residual & 5.143 & 27 & 0.190 & & \\
& Total & 6.300 & 29 & & & \\
\hline
\end{tabular}

\section{Conclusions}

The conclusions were based on the summary of our findings in the analysis. These were as follows:

There was a statistically significant relationship between the level of income of females and their marital status, $\mathrm{P}<0.05(\mathrm{df}=6, \mathrm{P}=0.0001)$ as observed in Table 2.

There was a statistically significant relationship between the level of education for women and marital status, $\mathrm{P}<0.05(\mathrm{df}=6, \mathrm{P}=0.0001)$ as revealed in Table 4.

There was a statistically significant relationship between number of income generating activities of women and marital status, $\mathrm{P}<0.05(\mathrm{df}=6, \mathrm{P}=0.0001)$ as revealed in Table 6.

There was a statistically significant relationship between the level of income of males and their marital status, $\mathrm{P}<0.05(\mathrm{df}=6, \mathrm{P}=0.049)$ as observed in Table 8.

There was a statistically significant relationship between the level of education for men and marital status, $\mathrm{P}<0.05(\mathrm{df}=6, \mathrm{P}=0.0001)$ as revealed in Table 10 .

There was a statistically significant relationship between number of income generating activities of men and marital status, $\mathrm{P}<0.05(\mathrm{df}=6, \mathrm{P}=0.008)$ as revealed in Table 12.

Increase of girl child empowerment reduces singlehood by 0.252 as revealed in Table 13. The same table also reveals that increase of boy child neglect increases singlehood by 0.454 .

\section{Conflicts of Interest}

The author declares no conflicts of interest regarding the publication of this paper.

\section{References}

[1] Gichinga, E. (1996) Unmarried Mothers. Uzima Press, Nairobi. 
[2] Kayongo-Male, D. and Onyango, P. (1991) The Sociology of the African Family. Longman Inc., New York.

[3] Dalrock, L. (2013) Single-Mothers and the Failure of Christian Men: It Is Time to Man Up. http://www.dalrock.wordpress.com

[4] Government of Kenya (2012) The Probation of Offenders Act. Government Printer.

[5] Nguru, F. (2007) Single Adults in an African City. Daystar University Publications, Nairobi.

[6] Government of Kenya (2011) The National Gender and Equality Commission Act. Government Printer.

[7] Nyangena, E. (2018) The Tragedy of the Boy Child amid Souring Girl Child Empowerment.

https://www.easpublisher.com/media/features articles/EASJEHL 11 16-21 c9YHv 5X.pdf

[8] Juma, J. (2009) Don't Forget Educating the Boys. Iss Nairobi Office. Paper.

[9] Chege, F.N. and Sifuna, D.N. (2006) Girls' and Women's Education in Kenya: Gender Perspectives and Trends. Unesco.

[10] Government of Kenya (2010) The Constitution of Kenya 2010. Government Printer.

[11] United Nations (1995) The Fourth World Conference on Status of Women September 1995. Beijing.

[12] Kimathi, G. (1994) Your Marriage and Family. Series F2. No. 58, Institute for Reformational Studies, Potchefstroom.

[13] Bundi, P. (2018) Why Girl Child Empowerment Is Killing the Boy Child. Paper.

[14] Radeny, S.M. (2003) Single-Motherhood and Its Implications: The Case of Kisumu City, Kenya. Ph.D. Thesis, Department of Sociology, University of Nairobi, Nairobi.

[15] Government of Kenya (2013) Basic Education Act No. 14 of 2013. Government Printer.

[16] Hamasi, L. (2013) The Boy Child and New Gender Imperatives in Kenya: Investigating School Dropout among Boys in Marakwet County. http://diplomacy.ku.ac.ke/index.php/faculty/faculty-profiles/87-faculty/568-dr-linn et-hamasi?start=1

[17] Kiunacarol, L. (2015) Empower Boy-Child to Strengthen Future Fathers. https://www.linkedin.com/pulse/empower-boy-child-strengthen-future-fathers-car oline-kiuna

[18] Kriel, J.D. (1991) Traditional Marriages amongst Blacks. Lantern, 40, 27-29.

[19] Baloyi, M.E. (2010) Pastoral Care and the Agony of Female Singleness in the African Christian Context. In die Skriflig, 44, 723-742.

https://doi.org/10.4102/ids.v44i3/4.169

[20] Reynolds, J. (2008) The Single Woman. Routledge, London.

[21] UNICEF (1989) Convention on the Rights of the Child. Paper.

[22] United Nations Educational Scientific and Cultural Organization (UNESCO) (2010) Education Counts: Towards The Millennium Development Goals. UNESCO, New York. 